TAPROBANICA, ISSN 1800-427X. October, 2012. Vol. 04, No. 02: pp. 88-91.

(C) Taprobanica Private Limited, 146, Kendalanda, Homagama, Sri Lanka.

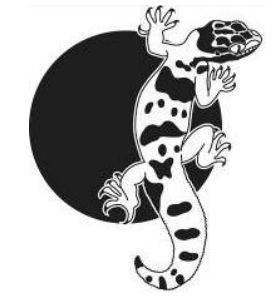

\title{
The Nasalis Affair
}

Lee E. Harding

SciWrite Environmental Sciences Ltd., 2339 Sumpter Drive, Coquitlam, British Columbia, Canada E-mail: harding@sciwrite.ca

Baron Friedrich van Wurmb (1781) is credited with the first description of the proboscis monkey, endemic to Borneo, which he named Cercopithecus [now Nasalis] larvatus. This was in a paper read to The Society of Batavia, modern day Jakarta, Indonesia, and later published in the Society's Memoirs. But he was not the first.

The late 18th Century must have been a wonderful time to be a naturalist —or, at least, a rich one. As the imperial powers of Europe scoured the globe for business opportunities, they saw the value of biodiversity. Their military and trading expeditions included naturalists who sent home many tonnes of specimens of animals and plants. The literati back home were amazed at the endless variety of organisms inhabiting these far-flung lands, and many nobles of wealth-who funded the expeditions - made a hobby of collecting them. King Louis XIII of France was one of these and his collection in the Jardin du Roi [the King's Garden] would become the foundation of the Muséum national d'Histoire naturelle in Paris. Carl Linnaeus (or Linné, which he adopted after he was made a nobleman) had published his first edition of Systema Naturae in 1735, with revisions and extensions as new specimens poured in, culminating in the tenth edition in 1758, the starting point for modern zoology. Taxonomists pored over the collections, categorizing and naming new species. Artists hurried to illustrate folios of strange plants and animals, lithographers made prints of them, and publishers rushed to publish.

One of the greatest taxonomists of his day-or ever-was the French noble, Georges-Louis Leclerc, Comte de Buffon (1707-1788). In 1742, he was given the task of describing the animals in the cabinet du Roi (then as now, extensive biological collections were kept in cabinets with arrays of drawers), for which he enlisted the help of his protégé, Louis Jean Marie Daubenton (1716-1799). Under Buffon's tutelage, Daubenton became a member of the French Academy of Sciences as an adjunct botanist, and Buffon appointed him curator of the king's cabinet. The 36 volumes of their jointly authored "Histoire Naturelle, Générale et Particulière, avec la Description du Cabinet du Roi" began coming out in 1746 . Volume 14 on primates appeared in 1766 with Daubenton authoring an introductory section on "Nomenclature des Singes" [Nomenclature of the Monkeys] and detailed anatomical descriptions of 18 species-not, however, including Nasalis larvatus (Buffon \& Daubenton, 1766). 
But Buffon \& Daubenton (1766) had a famous falling-out. For two centuries and more, scholars have speculated on the cause of the conflict (e.g., Farber, 1975), but the two never wrote of it themselves. Buffon dropped most of Daubenton's detail from the descriptions in the 2nd edition (Buffon, 1789) and dropped Daubenton as co-author, even though the latter continued working on his anatomical descriptions of monkeys and apes. This edition included a brief description of $N$. larvatus, which Buffon named the "guenon à long nez [long-nosed monkey]" crediting van Wurmb (1781) for the Latin name and description. "Guenon" was a generic term for what we now recognize as the tribe Colobini, of which the proboscis monkey is a member. Buffon's 1789 Histoire Naturelle included lithographs of a male and female proboscis monkey. The Avertissement (Introduction) written by Bernard Germain-Étienne Lacépède (who in 1799, after Buffon's death, would publish a revised edition of the Histoire Naturelle), said "M. Daubenton se propose de publier un Memoire au sujet de cet animal remarquable [Mr. Daubenton intends to publish a monograph about this remarkable animal]."

Meanwhile, Johann Christian Daniel von Schreber, a student of Linnaeus, was translating Linnaeus' work and writing a German-language compendium on mammals of the world, Die Säugethiere [The Mammals]. Von Schreber's (1775:46, Plates 10B and 10C) hand-coloured engravings of the proboscis monkey, "Simia nasica," obviously by someone who had never seen one alive (Fig. 1), were the clearly basis for Buffon's (1789: Plates XI and XII) lithographs of the "guenon à long nez." So the questions are: where did von Schreber, in Germany, see a specimen or drawing of the proboscis monkey five years before van Wurmb's paper in Indonesia? And why did von Schreber name it "nasica"?

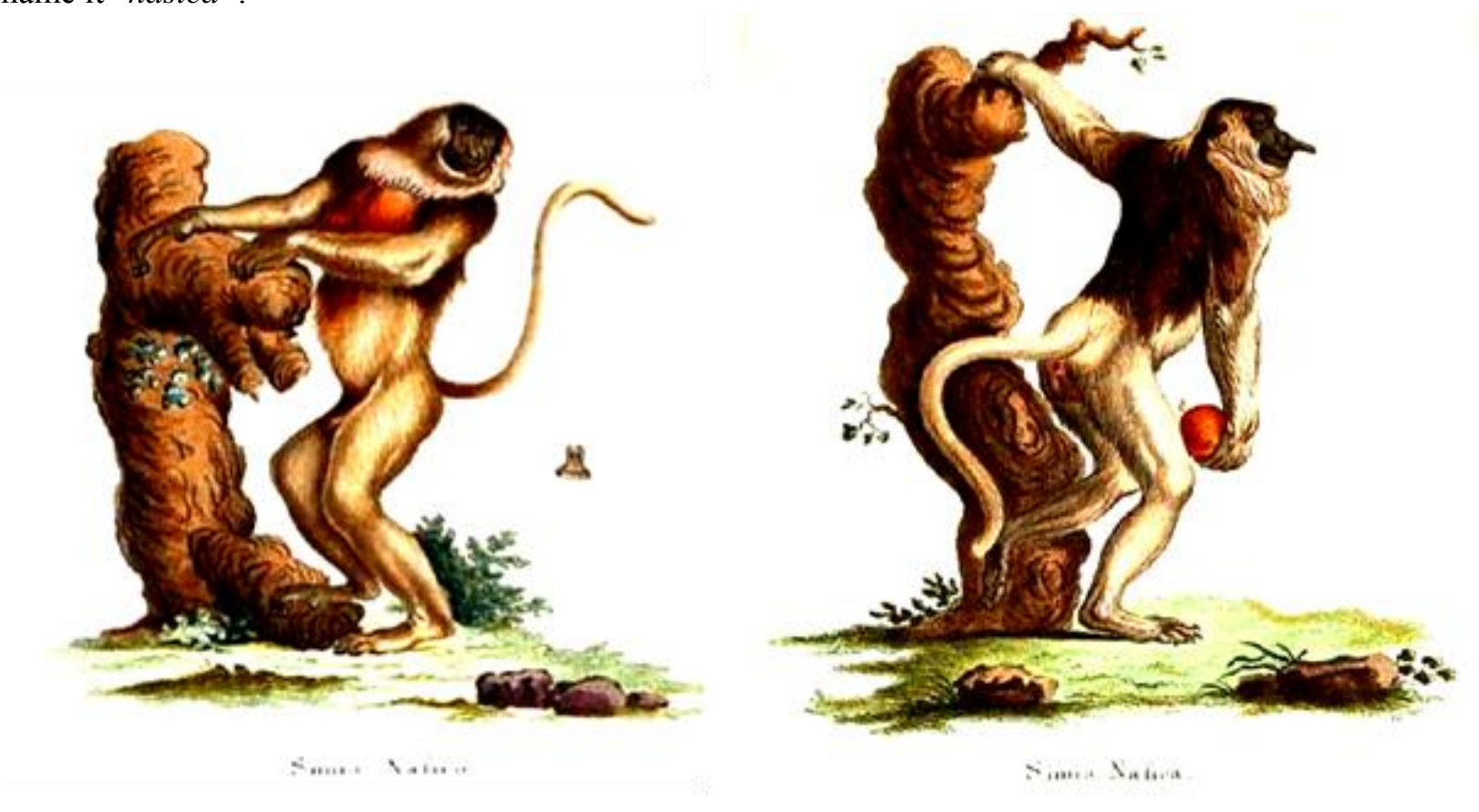

Figure 1: Von Schreber's 1775 hand-coloured engravings of the proboscis monkey (male, left; female, right) are the first published illustrations, are the first to use the name "nasica" and are identical in posture, background and details to Buffon's 1789 lithographs (reproduced from Von Schreber, 1775: 46, Plates 10B \& 10C).

Several early authorities (e.g., Cuvier, 1817; Cuvier, 1827; Geoffroy, 1812; Gervais, 1854; Lesson, 1834; Martin, 1837) refer to Daubenton's 1781 or earlier description of "le nasique," in the Mémoire de l'Institut National des Sciences et Arts, as the basis for the synonyms nasica, nasicus, and, ultimately, Nasalis. According to the British naturalist, William Charles Linnaeus Martin (1841: 456).

"Daubenton had previously [i.e., before van Wurmb's description] read a memoir respecting it, before the Academy of Sciences at Paris; but this paper was never published : there is no allusion to it in the Supplement to Buffon's Nat. Hist, vii., where the animal is figured and described under the title of 'Guenon a longue nez'; and whether the memoir on the 'Nasique' by Daubenton, be still in 
existence, and, if so, what may be the details and statements it contains, we have no means of ascertaining."

In fact, it was Étienne Geoffroy Saint-Hilaire (1812) who elevated the proboscis monkey to its own genus and renamed it Nasalis larvatus, combining Daubenton's nasique for the genus with van Wurmb's larvatus for the species. Significantly, in listing the previous synonyms, Geoffroy SaintHilaire cites von Schreber for the name Simia nasica after citing Daubenton for nasique, before citing Buffon for Guenon à long nez (not in italics), and before van Wurmb's Cercopithecus larvatus.

Daubenton's detailed description of the proboscis monkey was not printed until after Buffon's death in 1788. It appeared in the "Sonnini Edition" of the Histoire Naturelle (Buffon \& Sonnini, 1799). Later French naturalists continued to credit Daubenton for his description of "le nasique." Deterville \& Sonnini (1803:536), for example state that Buffon's guenon a long nez “...c'est le nasique de Daubenton [is the nasique of Daubenton]", and Gervais (1854:59) states, "On en doit la première description à Daubenton, qui l'a fait connaitre, dans l'Histoire de l'Académie des sciences. M. Wurmb en a parlé depuis dans les Mémoires de la societé de Batavia [We owe the first description to Daubenton...in the memoirs of the Academy of Sciences. Mr. Wurmb later discussed it in the Memoires of the Society of Batavia]." Daubenton's non-Linnaean nasique, although not available for nomenclatural purposes, is of historical interest as the probable source for von Schreber's (1775:46, Plates 10B and 10C) illustrations of Simia nasica.

Why wasn't Daubenton's monograph ever published? Could it have been related to the famous fight between him and Buffon? In three days of searching during April 2012, with the help of archivists, I could not find any papers by Daubenton on "le nasique" in either the French National Library rare book collection or National Museum of Natural History archives. I did, however, find 26 letters from Buffon to Madame Daubenton. They began shortly after Daubenton's February 1772 marriage to the former Mlle. Anne-Marie-Bernarde Boucheron, and continued through 1786. Some were clearly love letters. Buffon sent Daubenton's wife precious gifts and expressed his love for her in so many words. And she wrote to him: his letter of 26 July 1773, for example, says, "J'ai reçu toutes vos lettres, j'y ai vu le zèle de votre tendre amitié [I received all your letters, and saw the zeal of your tender affection]." His letter in May 1772, says, "je vous aime autant que vous pouvez les aimer [I love you as much as one can love]." The historical footnotes that archivists appended to this letter say that Madame Daubenton, then 26 (Daubenton was 33) was "very pretty" and had an "easy manner of the imagination, mind and heart" - a strong temptation, indeed, for one of the most powerful men in Paris. Another footnote says that, on the Daubentons' honeymoon in Paris, "Madame Daubenton was greeted eagerly by all the characters in relation to Buffon, and the circle of scholars from the Jardin du Roi." Can this imply a somewhat public knowledge of the affair?

We may speculate that Buffon's love for Madame Daubenton could explain the mysterious enmity between the two colleagues. It is even possible that Buffon, who controlled the affairs of Academy of Sciences, in some sort of reverse pique, suppressed the publication of Daubenton's monograph on the proboscis monkey. The Nasalis affair is, however, but a footnote in the DaubentonBuffon clash that is better known for the divergent approaches they took to theories of evolution (e.g., Butler, 1882; Farber, 1975; Wilkie, 1956).

Surrounding the Muséum National d'Histoire Naturelle are streets named after the great naturalists who constitute foundations of modern zoology, including most of those named above: Rue [Street] Cuvier, Rue Geoffroy-Saint-Hilaire, Rue Lacépède, Rue Linné, Rue Daubenton, and Rue Buffon. Daubenton and Buffon streets are nearly parallel to each other and converge as they near the Museum from opposite directions; but they never quite meet.

\section{Literature Cited}

Buffon, G. L. L., 1789. Histoire naturelle, générale et particulière. Supplément. À l'histoire des animaux quadrupèdes. Tome septiéme, Imprimerie Royal, Paris.

Buffon, G. L. L. and L. J. M. Daubenton, 1766. Histoire naturelle, générale et particulière, avec la description du cabinet du roi. Tome quatorzième, Plassan, Paris.

Buffon, G. L. L. and C. S. Sonnini, 1799. Histoire Naturelle, Générale et Particulière. Tome trentecinquieme, F. Dufart., Paris. 
Butler, S., 1882. Evolution, old and new; or, The theories of Buffon, Dr. Erasmus Darwin, and Lamarck, as compared with that of Mr. Charles Darwin. Occasional paper 4, S. E. Cassino, Salem.

Cuvier, F., 1817. Le règne animal distribué d'après son organisation, pour servir de base à l'histoire naturelle des animaux et d'introduction à l'anatomie comparée. Tome 1, Deterville, Paris.

Cuvier, G., 1827. A synopsis of the species of the class Mammalia. In: The animal kingdom arranged in conformity with its organization, Cuvier, G. and E. Griffith (eds.). Geo. B. Whittaker, London: 2-391.

Deterville, J. -F. -P. and C. -N. -S. Sonnini De Manoncourt (eds.), 1803. Nouveau dictionnaire d'histoire naturelle, appliquée aux arts, principalement à l'agriculture et àl economie rurale et domestique: par une société de naturalistes et d'agriculterus; avec des figures tirés des trois règnes de la nature. Tome XX Société de Naturalistes et d'Agriculteurs, Paris.

Farber, P. L., 1975. Buffon and Daubenton: divergent traditions within the Histoire naturelle. Isis, 66: 6374.

Geoffroy, S-H, É., 1812. Tableau des quadrumanes, ou des animaux composants le premier ordre des la classe des mammifères. Tome dix-neuvieme. In: Annales du museum d'historie naturelle, Cuvier, F. G. (ed.). Dufour et Compagne, Paris: 85-170

Gervais, P., 1854. Histoire naturelle des mammifères, avec l'indication de leurs moeurs, et de leurs rapports avec les arts, le commerce et l'agriculture Tome I Primates, Cheiroptères, Insectivores et Rongeurs. Tome I, L. Curmer, Paris.

Lesson, R. P., 1834. Histoire naturelle generale et parciculiere de mammiferes et des oiseaux decouverts depuis la mort de Buffon. Tome IV Suite des Mammiferes, Pourrat Freres Editeurs, Paris.

Martin, W. C. L., 1837. Notes on the anatomy of the proboscis monkey (Simia nasalis). Proceedings of the Zoological Society of London, 5: 70-73.

Martin, W. C. L., 1841. A general introduction to the natural history of mammiferous animals: with a particular view of the physical history of Man and the more closely allied genera of quadrumanes, or monkeys. Vol. 1, Wright and Co., London.

Van Wurmb, F., 1781. Verhandelingen van het Bataviaasch genootschap van Kunsten en Wetenschappen. III, Batavia [Jakarta].

Von Schreber, J. C. D., 1775. Die säugethiere in abbildungen nach der natur mit beschreibungen. Vol. I, Wolfgang Walther, Erlangen.

Wilkie, J. S., 1956. The idea of evolution in the writings of Buffon. Annals of science, 12: 48-62. 